Provided for non-commercial research and education use. Not for reproduction, distribution or commercial use.

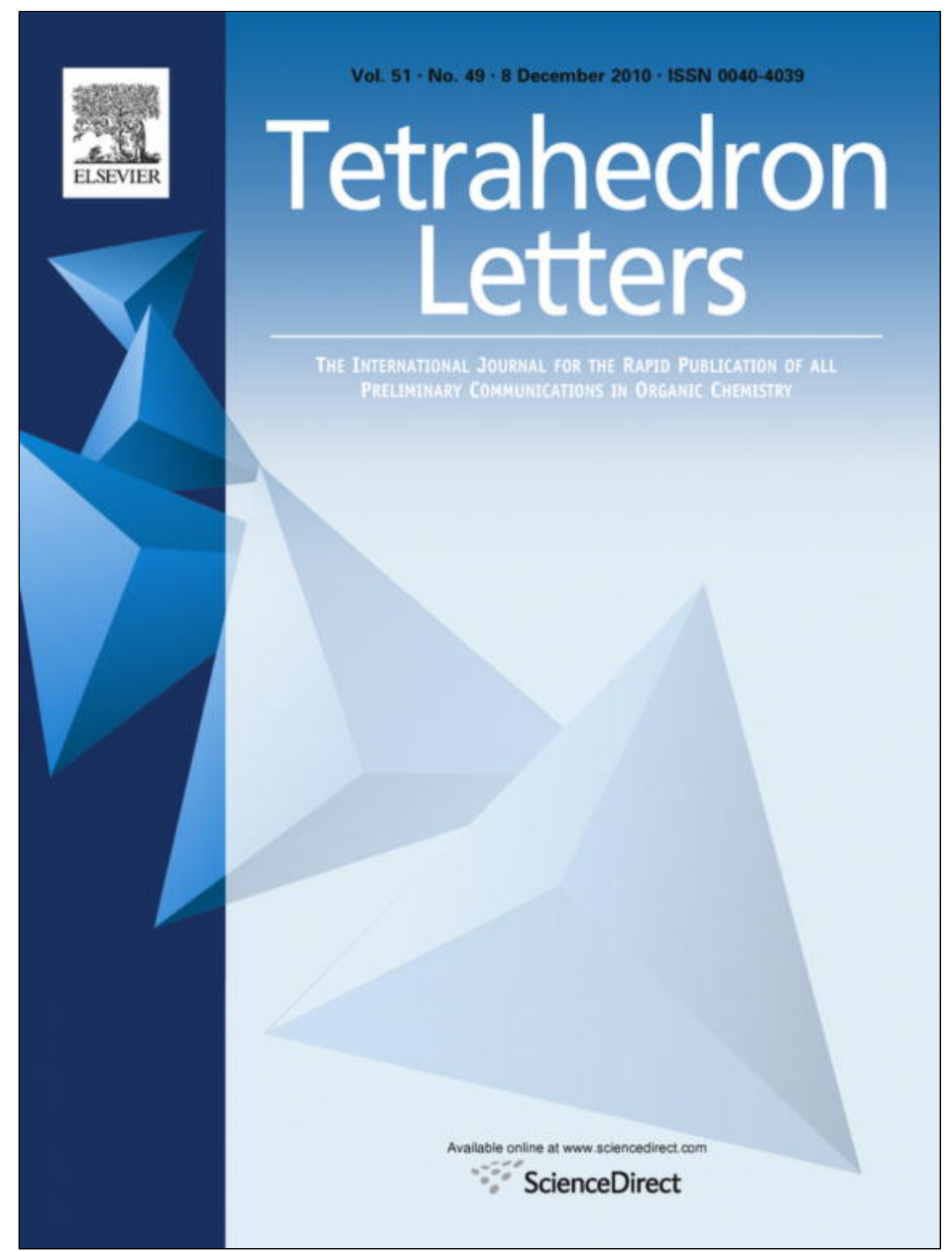

This article appeared in a journal published by Elsevier. The attached copy is furnished to the author for internal non-commercial research and education use, including for instruction at the authors institution and sharing with colleagues.

Other uses, including reproduction and distribution, or selling or licensing copies, or posting to personal, institutional or third party websites are prohibited.

In most cases authors are permitted to post their version of the article (e.g. in Word or Tex form) to their personal website or institutional repository. Authors requiring further information regarding Elsevier's archiving and manuscript policies are encouraged to visit:

http://www.elsevier.com/copyright 


\title{
An expedient synthesis of orthogonally protected lysinoalanine from Aloc-protected Garner's aldehyde
}

\author{
Cindy Körner ${ }^{a}$, Eun-Ang Raiber ${ }^{a, \dagger}$, Samuel E. M. Keegan ${ }^{a, t}$, Daniel C. Nicolau ${ }^{a, b}$, Tom D. Sheppard ${ }^{a}$, \\ Alethea B. Tabor ${ }^{\mathrm{a}, *}$ \\ a Department of Chemistry, UCL, 20, Gordon Street, London WC1H OAJ, UK \\ ${ }^{\mathrm{b}}$ Institute of Chemical Biology, Imperial College London, Exhibition Road, SW7 2AZ, UK
}

\section{A R T I C L E I N F O}

\section{Article history:}

Received 11 August 2010

Revised 5 September 2010

Accepted 24 September 2010

\section{Keywords:}

Garner's aldehyde

Lantibiotic

Lysinoalanine

Reductive amination

Cinnamycin

\begin{abstract}
A B S T R A C T
An expedient synthesis of orthogonally protected lysinoalanine has been developed. We have prepared a novel Garner's aldehyde derivative bearing an Aloc group; reductive amination of this aldehyde with Fmoc-Lys-OPMB gave the lysinoalanine skeleton. This was then transformed into an orthogonally protected lysinoalanine derivative suitable for the synthesis of side-chain bridged cyclic peptides by solid phase peptide synthesis methods.
\end{abstract}

(c) 2010 Elsevier Ltd. All rights reserved.
The unusual bis-amino acid lysinoalanine (1) is a key component of the cinnamycin group of type B lantibiotics. The lantibiotics are a family of highly complex peptide antibiotics, produced by Gram-positive bacteria. ${ }^{1}$ These peptides contain one or more of the unusual bis-amino acids lanthionine (Lan) and methyllanthionine (MeLan). Peptides incorporating these thioether analogues of cystine have multiple cyclic structures with thioether bridges between amino acid side chains. In the cinnamycin family of lantibiotics, the lanthionine bridges are nested, resulting in a very compact structure. In addition, these peptides contain one lysinoalanine residue, which forms an additional bridge between the C-terminus and the sixth residue (Fig. 1). In recent years there has been intense interest in the lantibiotics, arising from their intriguing biochemical properties. ${ }^{1,2}$ Cinnamycin has antibacterial activity, ${ }^{2}$ and also inhibits phospholipase $\mathrm{A} 2$ by specifically recognising and binding to phosphatidylethanolamine (PE) and lysophosphatidylethanolamine (lysoPE). ${ }^{2}$ It therefore has potential as a lead structure for the development of both antiinflammatory and antibacterial drugs. Hence, there is a need to synthesise cinnamycin, and simplified subunits and analogues, in order to develop the lead structure.

\footnotetext{
* Corresponding author. Tel.: +44 (0) 207679 4695; fax: +44 (0) 2076797463.

E-mail address: a.b.tabor@ucl.ac.uk (A.B. Tabor).

${ }^{\dagger}$ Present address: Cancer Research UK, Cambridge Research Institute, Li Ka Shing Centre, Robinson Way, Cambridge CB2 ORE, UK.

* Present address: Reading Science Centre, Pepper Lane, Reading RG6 6LA, UK.
}

Lysinoalanine (1) has also been isolated from proteins that have undergone treatment with alkali. ${ }^{3}$ In both cases, lysinoalanine is

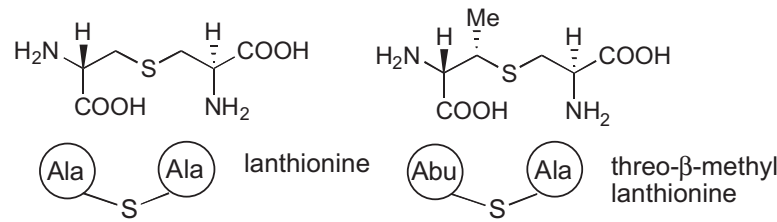<smiles>NC(CCCCNCC(N)C(=O)O)C(=O)O</smiles><smiles>c1ccc(Nc2ccccc2)cc1</smiles>

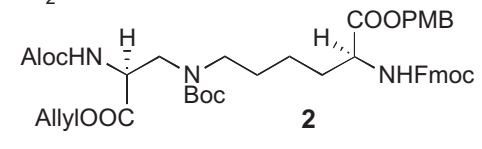

lysinoalanine 1

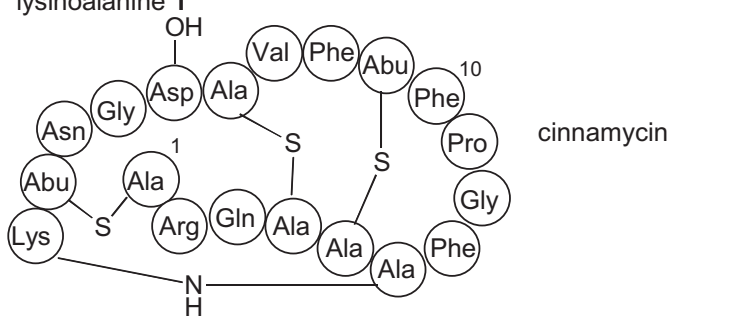

Figure 1. Cinnamycin and component bis-amino acids. 
believed to be formed from the addition of the $\varepsilon-\mathrm{NH}_{2}$ group of lysine to a dehydroalanine residue, which in turn is formed via dehydration of serine. In the cinnamycin family of lantibiotics both steps are probably catalysed by one or more enzymes to give a single diastereoisomeric product, although these enzymes have not yet been isolated or characterised. ${ }^{1 \mathrm{~b}}$ Conversely, in proteins that have been treated with alkali a mixture of diastereoisomers is formed. $^{3}$

We recently developed a powerful approach to the on-resin synthesis of lanthionine-bridged peptides. ${ }^{4}$ This requires the preparation of differentially protected lanthionine, in which one pair of amino and carboxy moieties bear allyloxycarbonyl (Aloc) and allyl protecting groups, and the other pair is protected with an Fmoc group only. As the allyl and Aloc groups are orthogonal to both the transient (Fmoc) and permanent (Boc) protecting groups used in conventional solid-phase peptide synthesis, this enabled us to incorporate these protected lanthionines into linear peptides, followed by selective deprotection of the allyl and Aloc groups, cyclisation and further chain extension, to give analogues of ring $C$ of the lantibiotic nisin. ${ }^{4}$ Vederas and co-workers have used this approach in the first total synthesis of the lantibiotic bis(desmethyl) lacticin $3147 \mathrm{~A} 2^{5}$ and of lactocin $S .{ }^{6}$ Other groups have also published syntheses of differentially protected lanthionine derivatives suitable for solid-phase peptide synthesis. ${ }^{7}$ We have also synthesised differentially protected $(2 S, 9 R)$-diaminodecanedioic acid and used similar methodology to incorporate this in peptides to give aliphatic bridges between amino acid side chains, ${ }^{8}$ whilst Vederas and co-workers have synthesised meso-3-(oxa)diaminopimelic acid and used this to make an oxa-analogue of lacticin A2. ${ }^{9}$

In order to use this methodology to synthesise lantibiotics such as cinnamycin, a reliable synthesis of the correct diastereoisomer of the protected lysinoalanine $\mathbf{2}$ was required. As with the protected lanthionine derivatives used in our earlier work, ${ }^{4}$ we required the lysine-derived moiety to be protected with Fmoc/ PMB groups, the serine-derived moiety to be protected with Aloc/allyl groups, which would be selectively removed prior to on-resin peptide cyclisation and the secondary amine to be protected with a Boc group (compatible with other side-chain protecting groups in the peptide). Previously published syntheses followed biomimetic routes ${ }^{3}$ via Michael addition of the $\varepsilon-\mathrm{NH}_{2}$ group of lysine to dehydroalanine. These synthetic routes generally afforded the unprotected bis-amino acid, which would be challenging to convert into the required differentially protected amino acid. In addition, synthesising heteroatom-bridged bis-amino acids by Michael addition to dehydroalanine derivatives leads to a mixture of diastereoisomers at the alanine-derived chiral centre. ${ }^{3,10}$ We therefore needed to develop a new route that would afford a differentially protected bis-amino acid and would also preserve the chiral integrity of the two $\alpha$-amino acid centres.

We envisaged that the key coupling step could be carried out by reductive amination between a suitably protected lysine derivative 3 and Garner's aldehyde (Scheme 1) to form the secondary amine bridge. In order to minimise the number of protecting group manipulations after this step, we required Aloc-protected Garner's aldehyde, 4. Although Boc-Garner's aldehyde ${ }^{11,12}$ is well-known and widely used, and the Cbz- and COOMe analogues have been described, ${ }^{13}$ the Aloc-protected version had not been previously prepared. As we required the $(R)$-aldehyde for our synthesis, we elected to start from D-serine. (The alternative route to $(R)$-Garner's aldehyde from L-methionine ${ }^{11 c}$ was not investigated, as the final step of this synthesis involves the oxidative cleavage of a double bond, which would not be compatible with the Aloc or allyl groups.) Aloc-D-Ser-OMe was prepared by esterification followed by Aloc protection, and converted into the oxazolidine $\mathbf{5}$ using 2,2-dimethoxypropane with $\mathrm{BF}_{3} \cdot \mathrm{OEt}_{2}$ as the catalyst. ${ }^{14}$ This was then followed by $\mathrm{LiBH}_{4}$ reduction ${ }^{15}$ to afford alcohol 6. Finally,
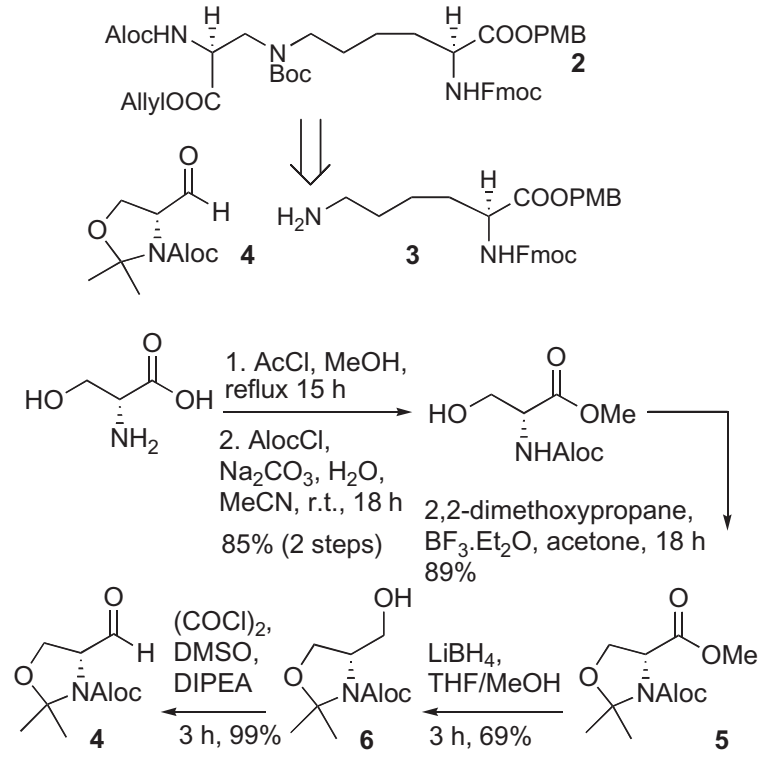

Scheme 1. Synthesis of Aloc-Garner's aldehyde.

aldehyde $\mathbf{4}$ was prepared via a modified Swern oxidation using diisopropylamine. ${ }^{16,17}$ The entire procedure could be expediently carried out in $52 \%$ overall yield on $0.5-5 \mathrm{~g}$ scales.

Fmoc-Lys-OPMB 3 was readily prepared from the available Fmoc-Lys(Mtt)-OH in two steps (Scheme 2). Reductive amination ${ }^{18}$ with $\mathbf{4}$ afforded the secondary amine $\mathbf{7}$ in moderate yield after purification. However, this material turned out to be unstable, with loss of the Fmoc group observed even during storage at $-20^{\circ} \mathrm{C}$, which we attribute to intramolecular deprotection by the secondary amino group. A two-step procedure, in which $\mathbf{7}$ was isolated and then immediately protected with di-tert-butyl dicarbonate, was more satisfactory and gave $\mathbf{8}$ in good yield. Selective deprotection of the $\mathrm{N}, \mathrm{O}$-isopropylidene group in the presence of the acidlabile PMB and Boc groups required careful optimisation. Treatment with $80 \%$ acetic acid at room temperature, ${ }^{19}$ or $\mathrm{BiBr}_{3},{ }^{20}$ gave no reaction, whilst with $1 \mathrm{M} \mathrm{HCl}^{21}$ partial PMB cleavage was observed in addition to removal of the $\mathrm{N}, \mathrm{O}$-isopropylidene. Selective deprotection was finally achieved with $p$-toluenesulfonic acid to give the alcohol $\mathbf{9}$.

The presence of the acid- and base-labile protecting groups, together with the double bonds in the Aloc and allyl groups, meant that a very mild method for oxidation of $\mathbf{9}$ into the carboxylic acid was also required. TEMPO/NaOCl oxidation was unsuccessful probably due to addition of hypochloric acid to the allylic groups. ${ }^{22}$ TPAP/NMO oxidation ${ }^{23}$ was likewise unsuccessful, with only the aldehyde being formed as judged by mass spectrometry. However, with TEMPO/bis[(acetoxy)iodo]benzene (BAIB) ${ }^{24}$ good conversion into the carboxylic acid was seen without any removal of the labile protecting groups or oxidation of the allylic groups. Both this compound and $\mathbf{9}$ proved problematic to purify, resulting in low isolated yields. It was therefore expedient to carry out both the deprotection and oxidation steps without purification, and thence to form the allyl ester 2 by reaction with allyl bromide and $\mathrm{Cs}_{2} \mathrm{CO}_{3}$.

Reductive amination of Boc-protected Garner's aldehyde has previously been described ${ }^{25}$ and it has been demonstrated that the stereochemical integrity of the chiral centre is not compromised during the reaction. Likewise, imine derivatives of Garner's aldehyde have been successfully prepared and reacted with carbon nucleophiles. ${ }^{26}$ We did not, therefore, anticipate problems with the reductive amination of $\mathbf{4}$ to give $\mathbf{8}$. Although doubling of some peaks in the NMR spectra of $\mathbf{8}$ and $\mathbf{2}$ were seen at 25 C; on heating 

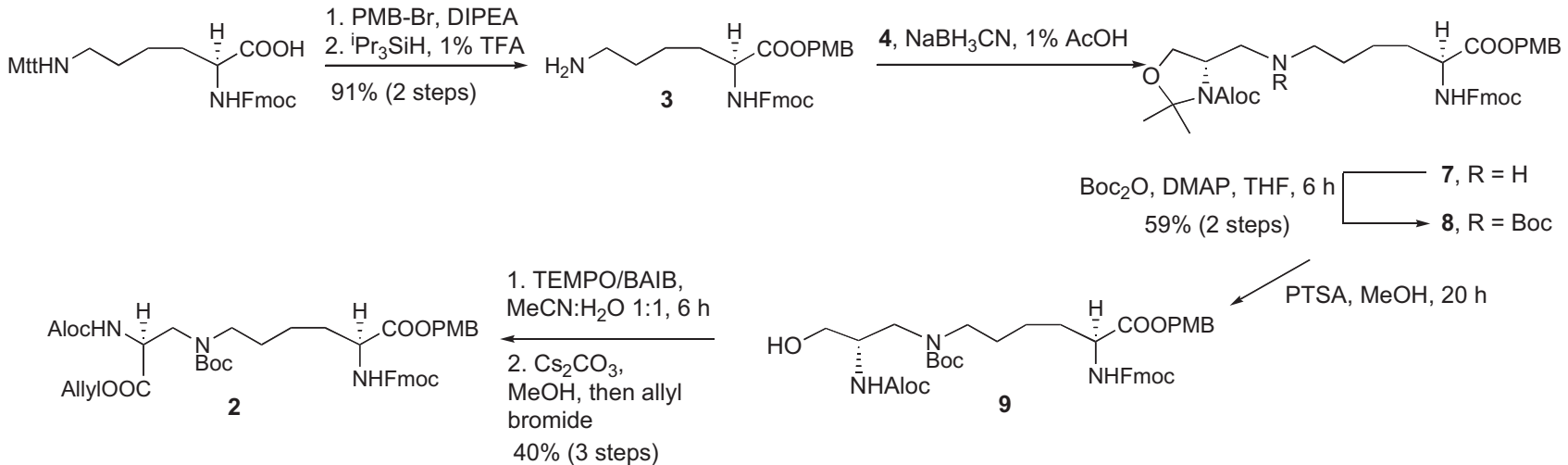

Scheme 2. Synthesis of protected lysinoalanine.

to $75 \mathrm{C}$ these resolved to give single peaks (Supplementary data), as was seen with the aldehyde $\mathbf{4}$, clearly indicating that a single diastereoisomer of the protected lysinoalanine derivative had been formed.

In summary, we have developed a synthetic route to lysinoalanine via the reductive amination of a novel Aloc-protected Garner's aldehyde derivative. The synthetic strategy ensures that the two carboxylic acid groups, and three amino groups, remain differentiated throughout, allowing the preparation of an orthogonally protected bis-amino acid. We envisage that this will be useful in the solid-phase preparation of a range of constrained peptides.

\section{Acknowledgements}

This work was supported by an Erasmus Grant from the European Commission (to C.K.), a BBSRC Grant BB/D005469/1 (to E.-A.R.), an EPSRC LSI Doctoral Training Centre Studentship (to D.C.N.) Grant EP/F500416/1, and an EPSRC Advanced Research Fellowship EP/E052789/1 (to T.S.)

\section{Supplementary data}

Supplementary data (experimental procedures, characterization data and ${ }^{1} \mathrm{H}$ and ${ }^{13} \mathrm{C}$ NMR spectra for all compounds, VT ${ }^{1} \mathrm{H}$ NMR spectra for aldehyde 4 and VT ${ }^{1} \mathrm{H}$ and ${ }^{13} \mathrm{C}$ spectra for the protected bis-amino acid 2) associated with this article can be found, in the online version, at doi:10.1016/j.tetlet.2010.09.119.

\section{References and notes}

1. (a) van Kraaij, C.; de Vos, W. M.; Siezen, R. J.; Kuipers, O. P. Nat. Prod. Rep. 1999, 16, 575-587; (b) Chatterjee, C.; Paul, M.; Xie, L.; van der Donk, W. A. Chem. Rev. 2005, 105, 633-683.

2. (a) Märki, F.; Hänni, E.; Fredenhagen, A.; van Oostrum, J. Biochem. Pharmacol. 1991, 42, 2027-2035; (b) Hosoda, K.; Ohya, M.; Kohno, T.; Maeda, T.; Endo, S.; Wakamatsu, K. J. Biochem. 1996, 119, 226-230.

3. (a) Hayashi, R. J. Biol. Chem. 1982, 257, 13896-13898; (b) Woodard, J. C.; Short, D. D.: Strattan, C. E.; Duncan, J. H. Food Cosmet. Toxicol. 1977, 15, 109-115; (c) Okuda, T.; Zahn, H. Chem. Ber. 1965, 98, 1164-1167.

4. (a) Mohd Mustapa, M. F.; Harris, R.; Bulic-Subanovic, N.; Elliott, S. L.; Bregant, S.; Groussier, M. F. A.; Mould, J.; Chubb, N. A. L.; Schultz, D.; Gaffney, P. R. J.; Driscoll, P. C.; Tabor, A. B. J. Org. Chem. 2003, 68, 8185-8192; (b) Mohd Mustapa, M. F.; Harris, R.; Esposito, D.; Chubb, N. A. L.; Mould, J.; Schultz, D.;
Driscoll, P. C.; Tabor, A. B. J. Org. Chem. 2003, 68, 8193-8198; (c) Bregant, S.; Tabor, A. B. J. Org. Chem. 2005, 70, 2430-2438.

5. Pattabiraman, V. R.; McKinnie, S. M. K.; Vederas, J. C. Angew. Chem., Int. Ed. 2008, 47, 9472-9475.

6. Ross, A. C.; Liu, H.; Pattabiraman, V. R.; Vederas, J. C. J. Am. Chem. Soc. 2010, 132, 462-463.

7. (a) Smith, N. D.; Goodman, M. Org. Lett. 2003, 5, 1035-1037; (b) Zhu, X.; Schmidt, R. R. Eur. J. Org. Chem. 2003, 4069-4072; (c) Narayan, R. S.; VanNieuwenhze, M. S. Org. Lett. 2005, 7, 2655-2658; (d) Cobb, S. L.; Vederas, J. C. Org. Biomol. Chem. 2007, 5, 1031-1038; (e) Martin, N. I. J. Org. Chem. 2009, 74, 946-949.

8. (a) Andrews, M. J. I.; Tabor, A. B. Tetrahedron Lett. 1997, 38, 3063-3066; (b) Alexander McNamara, L. M.; Andrews, M. J. I.; Mitzel, F.; Siligardi, G.; Tabor, A. B. J. Org. Chem. 2001, 66, 4585-4594.

9. (a) Liu, H.; Pattabiraman, V. R.; Vederas, J. C. Org. Lett. 2007, 9, 4211-4214; (b) Liu, H.; Pattabiraman, V. R.; Vederas, J. C. Org. Lett. 2009, 11, 5574-5577.

10. Probert, J. M.; Rennex, D.; Bradley, M. Tetrahedron Lett. 1996, 37, 1101-1104.

11. (a) Garner, P.; Park, J. M. J. Org. Chem. 1982, 52, 2361-2364; (b) Garner, P.; Park, J. M. Org. Synth. 1991, 70, 18-25; (c) Kumar, J. S. R.; Datta, A. Tetrahedron Lett. 1997, 38, 6779-6780.

12. For recent reviews, see: (a) Liang, X.; Andersch, J.; Bols, M. J. Chem. Soc., Perkin Trans. 1 2001, 2136-2157; (b) Hili, R.; Baktharaman, S.; Yudin, A. K. Eur. J. Org. Chem. 2008, 5201-5213.

13. (a) Beaulieu, L. P.; Schiller, P. W. Tetrahedron Lett. 1988, 29, 2019-2022; (b) Baxter, A. D.; Murray, P. J.; Taylor, R. J. K. Tetrahedron Lett. 1992, 33, 2331-2334; (c) Barco, A.; Benetti, S.; Spalluto, G.; Casolari, A.; Pollini, G. P.; Zanirato, V. J. Org. Chem. 1992, 57, 6279-6286.

14. (a) Moriwake, T.; Hamano, S.; Saito, S.; Torii, S. Chem. Lett. 1987, 2085-2088; (b) McKillop, A.; Taylor, R. J. K.; Watson, R. J.; Lewis, N. Synthesis 1994, 31-33.

15. Meffre, P.; Durand, P.; Branquet, E.; Le Goffic, F. Synth. Commun. 1994, 24, 2147-2152.

16. Dondoni, A.; Perrone, D. Synthesis 1997, 527-529.

17. At $25^{\circ} \mathrm{C}$ a doubling of the aldehyde and methyl signals was observed in the ${ }^{1} \mathrm{H}$ NMR spectrum, however, on heating to $75^{\circ} \mathrm{C}$ single, sharp peaks were observed (Supplementary data) indicating that at the lower temperature there is restricted rotation around one or more bonds. This behaviour has been observed previously, see: Garner, P.; Park, J. M. J. Org. Chem. 1987, 52, 23612364.

18. Chhabra, S. R.; Mahajan, A.; Chan, W. C. J. Org. Chem. 2002, 67, 4017-4029.

19. Dondoni, A.; Mariotti, G.; Marra, A. J. Org. Chem. 2002, 67, 4475-4486.

20. Cong, X.; Hu, F.; Liu, K.-G.; Liao, Q.-J.; Yao, Z.-J. J. Org. Chem. 2005, 70, 45144516.

21. Ohgi, T.; Kondo, T.; Goto, T. Tetrahedron Lett. 1977, 46, 4051-4054.

22. Anelli, P. L.; Biffi, C.; Montanari, F.; Quici, S. J. Org. Chem. 1987, 52, 2559-2562.

23. Xu, Z.; Johannes, C. W.; Houri, A. F.; La, D. S.; Cogan, D. A.; Hofilena, G. E.; Hoveyda, A. H. J. Am. Chem. Soc. 1997, 119, 10302-10316.

24. Epp, J.-B.; Widlanski, T. S. J. Org. Chem. 1999, 64, 293-295.

25. (a) Stanley, M. S. J. Org. Chem. 1992, 57, 6421-6430; (b) Araldi, G. L.; Donati, D.; Tranquillini, M. E.; Ursini, A. Il Farmaco 1998, 53, 49-54.

26. (a) Palomo, C.; Cossio, F. P.; Cuevas, C.; Lecea, B.; Mielgo, A.; Roman, P.; Luque, A.; Martinez-Ripoli, M. J. Am. Chem. Soc. 1992, 114, 9360-9369; (b) Fujisawa, T: Nagai, M.; Koike, Y.; Shimizu, M. J. Org. Chem. 1994, 59, 5865-5867; (c) Feldman, K. S.; Mingo, P. A.; Hawkins, P. C. D. Heterocycles 1999, 51, 1283. 